UDC 811:161.1-054.6

DOI: $10.17223 / 24109266 / 11 / 9$

\title{
PROFESSIONALLY-ORIENTED DISCOURSE IN ELT FRAMEWORK
}

\author{
T.V. Mordovina, E.Yu. Voyakina
}

\begin{abstract}
The paper deals with the peculiarities of forming and developing the discourse competence in ELT process. The methodological value of forming students' general idea of the professionally-oriented discourse is justified. The most relevant teaching technologies that meet the discourse approach in the process of teaching and learning a foreign language are presented.

Keywords: Professionally-oriented discourse, discourse competence, communicative situation, discourse-oriented teaching technologies.
\end{abstract}

\section{Introduction}

A discourse approach has been firmly rooted in teaching foreign languages as modern texts should be evaluated through the specific conditions of their creation and functioning. In this regard, we adhere to the communicative approach to the study of discourse, in which it is interpreted as a text immersed in a situation of communication, in life [1,2].

The importance of involving discourse in ELT is explained by the necessity to teach and study a foreign language not in isolation, but in context showing how a specific language phenomenon is used in one or another communicative situation. The discourse analysis also allows a specialist faced with a variety of unfamiliar communicative situations acquire the necessary professional skills to transfer discourse competence from one discourse space to another.

\section{Discourse vs text}

The text remains the basic concept in ELT, around which and on the basis of which the learning process is built, a new material is introduced, new exercises are created, language skills and abilities are developed, etc. The comparison of the concepts "discourse" and "text" allows to reveal the main distinctive features of the "discourse" phenomena. It becomes clear that discourse, besides the actual text, includes some extra-linguistic characteristics (communication participants, goals, intents and pragmatic attitudes, social roles, background knowledge, interlocutor knowledge, temporary and spatial conditions of communication) related to the described communicative situation. The discourse is distinguished by the integrity, which is manifested in the continuous connectivity of its components. In addition, the discourse is dynamic, i.e. it is considered as a process of both a speech work creating process and its results. 
Thus, the most significant characteristic of the discourse is that it is considered as a complex communicative phenomenon and includes, in addition to traditional linguistic parameters peculiar to the text, the social context giving the idea of both communication participants and their characteristics and the processes of the message production and perception.

\section{Professionally-oriented discourse as a basis of ELT}

The need for people having sufficient professional knowledge and skills, capable of making their own life strategies, possessing a high level of subjectivity, creativity, responsibility, decisiveness, ability to learn, analyze, predict, design is actualized which makes new demands on the quality of education at all levels. Therefore, solving problems related to mastering all the language functions in the academic process of learning foreign languages to form the discourse competence is a necessary condition for the achievement of modern specific learning goals.

The methodological value of forming students' general idea of the discourse (especially professionally-oriented) is that the skills and abilities of the discourse analysis contribute to understanding professionally-oriented texts, and for learning purposes - remembering the basic information included in the text. Of course, the formation of the discourse analysis skills by students is a rather complicated process. It includes the steps of learning how to structure professionally-oriented texts, sum them up, use different types of texts in bundles, various methods of work, e.g. as part of the Case Study technology, and elementary discourse analysis in preparing and conducting role-playing and business games.

As an example, we consider the economic discourse as a goal and means of mastering a foreign language by the students of economic specialties at Tambov State Technical University. The economic discourse, in relation to the modern society, is one of the types of institutional discourse. The specifics of the economic discourse is manifested in its aggregation with other types of the modern discourses. It also should be noted that the economic discourse can be presented in various genres, both written (economic reviews, articles), and oral (interviews, business negotiations, etc.).

Today, the economic discourse serves as an object of numerous studies due to the urgency of the issues discussed in the economic arena: globalization of the economy, Russia's entry into the world economic space, the financial and economic crisis, assistance to underdeveloped countries, threats of default, rising inflation, etc. Acquaintance with the most update information which is often presented in foreign books, journals, newspapers, websites, etc. is of high importance to the students mastering economic professions.

In its structure, the discourse represents a two-level formation - the unity of the content (some area of human knowledge or experience) and the 
form (language means that serve to verbalize this knowledge and experience). Elements of both levels can act as markers of the discourse. At the substantive level (the macrostructure in terms of T. van Dijk) the discourse is signaled by nuclear concepts, verbalized by the appropriate vocabulary; on the formally superficial level (superstructures in terms of T. van Dijk) grammatical and syntactic features and specific features of textual organization, typical for a certain sphere of communication. In our case, this is the world of economic phenomena and events, characterized by specific economic vocabulary.

The main focus of the discourse approach in ELT is not on the transfer of knowledge by the teacher to the student, but on the activation of the students' role and motivation to search for information and training keys. In this regard, the process of teaching a foreign language in the non-philological university should be structured according to specialized educational programs.

Applying the discourse approach, future specialists are taught not only formal characteristics (structure, linguistic) of different genres, but also its content part, mainly the extra linguistic features, which are realized through different discourse-categories. For example, in the process of training to write or rewrite professionally-oriented newspaper texts and titles for them, students acquire both grammar structures, syntax, vocabulary, language skills and its content, the main idea, pragmatics, intertextuality. Such work allows better and more accurate understanding of the text, more adequate perceiving of the described information. Then the students try to produce their own texts taking into account formal and extra linguistic features of the given communicative situation.

\section{Discourse-oriented teaching technologies}

The most relevant technologies that meet the discourse approach in the process of teaching and learning a foreign language are the following.

- The Project Technology implies students' motivation, interest and independence and develops creative learning. It also provides conversational practice and allows to reveal students' individuality by solving practical tasks or problems, which, in turn, requires the integration of knowledge from various subject areas. The teacher plays the role of coordinator, expert, additional source of information. Students work as a team, together with the teacher not only looking for extraordinary solutions, but also analyzing each step of their training, identifying shortcomings and mistakes, looking for causes of difficulties and finding the ways to correct errors. A teacher directing the discussion, suggesting the necessary vocabulary and refraining from correcting grammatical errors during the discussion (they will be discussed later) can bring the student not only to a new level of the language proficiency, but to introduce a new vision of the problem itself. 
The foreign literature describes the following stages of projectmaking:

- identifying the project main characteristics (topic, problems, goals, structure);

- making up a draft work plan, presenting the necessary language material and pre-communicative training;

- collecting the necessary information (working with information sources, creating the information storage system);

- group work (meetings during which students discuss intermediate results, ask questions);

- preparation and demonstration of the project presentation (the culmination point of the project);

- reflection and evaluation of the project.

During the project making process the teacher comments on the work done by the students, corrects mistakes in the use of language units, introduces and tests new language material, analyzes the collected information and coordinates actions of different groups, and finally evaluates the projects.

The project technology includes not only the control of mastering linguistic material and the development of the communicative competence, but also a general assessment of the project, which concerns its content, topics, outcome, participation of individual students in the project organization, etc. The communicative competence is developed by using the language in communicative situations close to the conditions of real communication, activating the independent students' work, choosing the topic of students' interest, selecting the language material, tasks and work sequence in accordance with the project topic, visual representation of the outcomes, evaluating and reflecting on the process and results of the project activities.

The analysis of the theoretical foundations of the project technology and the results of its application in practice suggests that projects provide new opportunities for solving methodological problems and help develop the discourse competence. At the same time, for successful use of this technology, it is necessary to take into account the specifics not only of a particular academic discipline, but also the features of each type of projects. Conducting a training course or its fragment on the basis of the project technology requires a highly qualified teacher, since for each project it is necessary to independently and very carefully select the necessary language material and develop an effective system of tasks and exercises. In addition, the inclusion of such projects in the educational process will require the solution of a number of organizational and psychological problems. The project technology is an efficient teaching method that significantly increases the mastering level of educational material, as well as the students' internal motivation and high level of their independence. 
The educational potential of the project activity lies in the possibility of increasing the students' motivation to obtain additional knowledge; studying the methods of scientific knowledge (put forward and substantiate the idea, independently formulate and formulate the project task, find a method for analyzing the situation); reflecting and interpreting the results; developing the research and creative abilities of students, forming the students' independence, responsibility to design their own trajectory of movement in solving problematic issues.

- The Case Study Technology helps students fully comprehend and analyze the proposed situation (case) instead of answering the questions on the text which helps them develop independence and initiative, remove barriers to using a foreign language. This technology is based on studying a specific business situation, real practice from the professional sphere which activates a complex of students' professional knowledge and skills in decision-making simulating a real business or problem situation. Thus, the case analysis is always a comprehensive solution, which is obtained by analyzing various options for making a final decision, which do not "filter" the main components of the problem, but find interesting, non-standard solutions, in other words, use integrated thinking.

The work in the classroom should be based on the following stages:

- lead-in (first reading the text of the case for gist in order to determine the general problem, then reading for detail);

- brief summary of the case;

- problem statement;

- distribution of roles;

- chronology of events;

- facts that led to the case problem (a number of opposing views on the current situation are presented);

- choice of solutions (it is recommended to propose at least five solutions to the problem, each option should have detailed arguments for and against);

- recommendation (one of the proposed options is selected, and this choice is reasoned);

- action plan (it is recommended to submit an action plan as detailed as possible to implement the decision made during the discussion)

- conclusion.

Thus, the development of integrative thinking through case study technology in a foreign language classroom gives students a sense of opportunity to apply their language and professional knowledge and skills in a specific situation, as well as gives rise to new ideas and innovative solutions.

- The Debate Technology allows to drill vocabulary and grammar structures, revise the studied material, involve students in independent selection of the necessary material and develop the ability to make arguments and defend their point of view on the stated problem in a foreign language. 
However, the debate technology has its own characteristics including not just a free exchange of views on a specific issue. This method is a formalized dispute according to certain rules which has a framework nature. The debate technology is distinguished by the presence of two opponents who are trying to convince a third party of the correctness of their position. The purpose of the debate is the most comprehensive study of a topic, the development of critical thinking, the ability to defend one's point of view, the tolerant attitude to someone else's view of the problem.

The debate technology is universal in nature, as it can be filled with any content, used in the study of any subject, since it is one of the ways of developing foreign language communicative competence on the one hand, and social interaction skills on the other. However, the specifics of a foreign language imposes its own characteristics on it.

Based on the experience of conducting foreign language classes with university students, we have compiled the following scheme for implementing the debate technology in practice:

- stating the debate problem (issue);

- preparing for the debate (reading the information on the debate, group or team discussion, making notes, distribution of roles);

- discussion of the debate problem (questioning, expressing arguments "for" and "against", reacting to the opposing arguments, discussing the information from the opposing team);

- reports of the opposing teams;

- making decisions (discussing the arguments provided and carrying out the final decision);

- reflection on the debate (assessing the arguments made by both teams, the language used, the manner of speaking, behavior, analyzing the difficulties experienced during the debate);

- making a conclusion (discussing ways of improving the debate organization and presentation, vocabulary, grammar, logic of speech, politeness conventions, tolerance, etc.).

Among the criteria for evaluating a dispute there are reasoned points of view, the ability to ask problematic questions, the behavior of participants in the debate, the observance of speech etiquette, using the topical vocabulary, phonetic design, etc.

Special attention should be paid to the necessary self-analysis of students, identifying the difficulties they encountered in the process, as they provide information on how to adjust the teacher's work (planning, repetition, etc.), as well as independent work students in the preparation of subsequent tasks.

\section{Conclusion}

The analysis of using the studied technologies in foreign language classes with university students of economic specialties shows that they have 
proved to be motivating and effective, as the students master not only the language skills and abilities but also apply their professional knowledge and skills and develop their professional competence in the sphere of economics. In the current situation of multilingualism, multiculturalism, globalization and informatization, the use of the project, case study and debate technologies when organizing foreign language classes for students undoubtedly contributes to the integration of students into the international educational and professional space and into modern dynamic living conditions, in general.

\section{References}

1. Arutyunova, N.D.: Yazyk i Mir Cheloveka. Moscow: Yazyki russkoj kul'tury (1999)

2. Karasik, V.I.: Yazykovoj Krug: Lichnost', Koncepty, Diskurs. Volgograd: Peremena (2002)

3. Beckett, G.H., Miller, P.C.: Project Based Second and Foreign Language Learning: Past, Present and Future. USA: Information Age Publishing, pp. 159-165 (2006)

4. Bychkov, A.V.: Metod Proektov v Sovremennoj Shkole. Moscow, Moscow University Publ. (2000)

5. Dijk, T.A. van: Yazyk. Poznanie. Kommunikatsiya. Blagoveshchensk: BGK im. I.A. Boduena de Kurtene (2000)

6. Hedge, T.: Key Concepts in ELT: Learner Training. ELT Journal, vol. 47, issue 1, pp. 92$93(2003)$

7. Bax, S.: Normalisation revisited: The Effective Use of Technology in Language Education. IJCALLT, vol. 1, issue 2, pp. 1-15 (2011)

8. Mil'rud, R.P., Maksimova, I.R.: Kommunikativnaya Kompetenciya kak Gotovnost' Uchashchihsya k Obshcheniyu na Inostrannom Yazyke. Yazyk i kultura, issue 38, pp. 250-268. (2017)

9. Pennington, M.C.: The Power of CALL. Houston: Athelstan, pp. 33-53 (1996)

10. Richards, J.C., Rodgers, T.S.: Approaches and Methods in Languages Teaching. Cambridge: Cambridge University Press (2001)

11. Thorne, S.L., Reinhardt, J.: 'Bridging Activities', New Media Literacies, and Advanced Foreign Language Proficiency. CALICO Journal, vol. 25, issue 3, pp. 558-572 (2008)

12. Waters, A.: Trends and Issues in ELT Methods and Methodology. English Language Teaching Journal, vol. 66, issue 4, pp. 440-449 (2012)

\section{Information about the authors:}

Mordovina T.V. - Ph.D., Associate Professor, Department of International Scientific and Professional Communication, Tambov State Technical University (Tambov, Russia). E-mail: voyackina.elena@yandex.ru

Voyakina E.Yu. - Ph.D., Associate Professor, Department of International Scientific and Professional Communication, Tambov State Technical University (Tambov, Russia). E-mail: voyackina.elena@yandex.ru 